\title{
The Perceived Economic Benefits of Tourism: The Case of a Rural Community Bordering the Kruger National Park in Limpopo Province, South Africa
}

\section{Tafadzwa Matiza}

Olabanji. A. Oni

Doi:10.5901/mjss.2014.v5n20p322

\section{Abstract}

A quantitative study was conducted to establish the perceptions of local community members with regards to the perceived economic benefits of tourism activities in their rural community. From a final population sample of $N=80$ households, a survey was conducted utilising researcher administered questionnaires, with responses recorded on a 5-point Likert scale. Data was sorted and analysed utilising the Statistical Package for Social Sciences 20.1, with descriptive data presented in tabular form summarising frequencies and cumulative frequencies per statement. The study importantly found that the community perceived itself to be benefitting economically from tourism activities, albeit the associated costs that could be attributed to tourism activities. Job creation, infrastructural development and improved standards of living were identified as key benefits for the rural populace, while social issues such prostitution were the perceived costs of tourism in the area adjacent to the Kruger National Park of Limpopo Province South Africa.

Keywords: Tourism, economic benefits, Kruger National Park, pro-poor tourism, rural tourism

\section{Introduction}

Tourism is considered to be one of the world's largest and most dynamic industries (Surungiu, 2009). As such, proponents of sustainable economic development view tourism as a potential growth catalyst for less developed nations and emerging economies such as South Africa. According to Mutana (2013), such an approach to tourism is referred to as pro-poor tourism (PPT). Similarly, Rathore (2012) and Holland, Burian and Dixey (2003) view tourism as a poverty alleviation tool given the sectors' labour intensive, inclusive (women) and informal (natural \& cultural-based assets) attributes. The economic benefits of tourism represent a key research area in tourism studies, with tourism practitioners and scholars alike finding key quantitative data pointing to tourism being economically beneficial to host tourism destinations. However, as Thompson (2007) and Surugiu (2009) point out, a variety of methods have been utilised to explore the economic benefits of tourism ranging from simple guesswork, to complex mathematical models and panel data to estimate the economic impact of tourism on tourism destinations. As can be expected, some of these analyses make little or no sense to non-economists.

With this in mind this study, although similarly quantitative in nature, focuses on establishing the perceived impact of tourism at a grass-roots level, within a sampled rural community bordering the Kruger National Park, Limpopo, South Africa. This study purposively ignores the macro-economic impact of tourism which is often analysed with particular reference to the gross domestic product (GDP) of the host tourist destination. The primary aim of the study was to determine the perceived economic impact of tourism on a rural community in South Africa's Limpopo Province. In order to achieve this aim, the study set the following objectives: a) To establish the perception of locals residing in a rural tourist destination bordering the Kruger National Park of Limpopo, South Africa regarding tourists and tourism activities in their locale; b) To determine the perceived socio-economic costs of tourism from the perspective of local residents residing in the rural area bordering the Kruger National Park of Limpopo Province, South Africa and; c) To assess the perceived economic impact of tourism from the perspective of local residents inhabiting the rural area bordering the Kruger National Park of Limpopo, South Africa.

The following research questions guided the empirical research process:

1) What are the existing perceptions of tourists and tourism activities amongst the residents of the sampled rural community bordering the Kruger National Park of Limpopo, South Africa? 
2) What socio-economic 'costs' do local residents associate with tourism activities within their rural community?

3) What are the perceived economic benefits of tourism from the perspective of local residents residing in the rural area adjacent to the Kruger National Park of Limpopo Province, South Africa?

\section{Review of Literature}

Rural tourism or tourism in rural areas is a new form of activity that can bring economic and social benefits to a rural community (Rathore, 2012; Bahrami \& Noori, 2013; Lo, Mohamad \& Yeo, 2013). This development of tourism in rural areas can be attributed to the realisation by the governments of developing countries that their natural resources (wildlife, flora and fauna, culture \& heritage) are tourist attractions, hence according to Holland et al (2003), some of the world's top tourist destinations like national parks (the Kruger National Park), wilderness areas (the Karoo), famous mountains (Table Mountain) and cultural \& heritage areas (the Cradle of Mankind in Maropeng) are located in South Africa's mostly rural areas. Most rural areas in South Africa are characterised by under-development, unemployment, and a general lack of basic infrastructure (Nzama, 2008) and in the case of South Africa the growth of tourism in rural areas has diversified the country's tourism product and has been well-marketed. As a result, South African rural areas have increasingly attracted more domestic and international tourists (Viljoen \& Tlabela, 2007) and are increasingly becoming more developed. However, Ashley and Roe (2002) caution that poverty alleviation and rural development are not central to the tourism concept and may not be the panacea to rural under-development as most would like to believe.

In a study on tourism and rural development in the rural Binga area of Zimbabwe, Matana (2013) notes that tourism is a key rural development approach since tourism: a) has less tariff and entry barriers making it a cheaper new venture option; b) has considerable linkages to other economic activities such as aqua-culture, hunting and wildlife conservation; c) tourists are naturally attracted to remote 'unspoilt' locations; d) is labour intensive and hence has the potential has the potential to provide much needed employment in rural communities and; e) is associated with infrastructure development such as roads, health facilities and other amenities that would have otherwise not be developed in the area. Lo et al (2013) elaborated that tourism has the capability to enhance the quality of life in rural communities, while accruing other economic benefits such as infrastructure development (water supply, roads, and clinics). Similarly, Viljoen and Tlabela (2007) view tourism as an integral part of economic development that drives economic expansion and creates much needed employment in South Africa.

As can be expected, the exploitation of any resources, natural or otherwise creates debate about the cost-benefit of the utilization of the resources in question (Fretchling, 2011). One of the main reasons developing countries promote and sustain tourism is the expected economic growth (Surugiu, 2009; Fretchling, 1994). The role of the receiving community in tourism is very important since tourism affects the whole community in one way or another, be it benefits (value accrued to the community such as income, jobs) or costs (the negative effects tourism activities could have on a community such as environmental degradation, pollution and crime). In the case of tourism in rural communities, Rathore (2012); Honey and Gilpin (2009) and; Tsundoda and Mendlinger (2009) identify the benefits of tourism to include;

- Employment creation for the host community

- Improvement and development of public services and infrastructure respectively

- Increase in local income levels

- Increase in demand for goods and services

- Improved standard of living for residents of the tourist area

While the costs of tourism include;

- Exploitation of the rural populace

- Urbanisation

- Repatriation of profits from the community

- Underpayment of rural labour

- Misuse of local infrastructure by visitors

- Increase in the cost of housing and land in the area

- Increased immigration of labour

Empirical studies have been conducted within rural communities in the developing world and reveal important aspects of tourism in predominantly rural areas;

- A study conducted in a Nigerian rural area found that tourism is a catalyst to socio-economic development with benefits accruing at all levels of society, making tourism a viable poverty alleviation tool (Framgialli, 2008).

- However, in Kenya, Western (2008) found that although there are cases of good tourism practice, a fair share 
of Kenyan tourism disregards local customs, is indifferent to natural resource conservation and does not equitably benefit the host communities.

- Similarly, in India Chachani (2008) found that tourism in rural areas is commonly associated with the displacement of locals and the destruction of traditional livelihoods resulting in locals being forced to take up low-paying and exploitative jobs in the tourism sector.

According to Tsundodu and Mendlinger (2009), studies have also shown that a community may be polarised with regards to the perceived impact of tourism within their community. As a result it is important to conduct studies within rural communities to assess the impact of tourism on local rural communities. With this in mind this study was conducted to establish the perceived economic benefits of tourism within a community adjacent to the Kruger national park, a world renowned game reserve.

\section{Methodology}

This study was conducted as a quantitative inquiry, focusing on the numerical representation of the perceptions of local residents with regards to the perceived economic benefits of tourism activities in the area.

\subsection{Population and Sample}

The sample population was drawn from the Skukuza area of Limpopo which borders the northern part of the Kruger National Park. The initial sampling procedure identified the following communities as the sampling frame:

- Makuleke Community

- Mhinga Community

- Matiyane Community

- Josefa Community

- Mabilingwe Community

- Makuhlule Community

- Bevhula Community

- Mashobye Community

- Magona Community

Simple random sampling was utilized to select one community as the sample population, where the names of the communities were placed in a hat and one paper was drawn at random to select the community to be sampled for the study. However, in the interest of confidentiality the selected community will not be identified.

A convenient sample was drawn, where each household in the small community was approached to participate in the survey, with one respondent being required for each household. Out of the initial sample of $N=93$ households in the community a significant number participated in the study.

\subsection{Data Collection and Analysis}

A quantitative survey was conducted to collect the data required for the study. Researcher administered questionnaire was the data generation instrument for the study, where the researcher interviewed the respondents and completed a pre-designed structured questionnaire with their responses to the Likert Scale based range of close ended responses. Analysis of data was aided by the use of the Statistical Package for Social Sciences (SPSS) 20.1, and data was presented in the descriptive form, in a table summarizing frequencies and cumulative percentages based on the raw data collected.

\section{Results}

An initial population of $N=93$ households was approached to participate in this study. As a result of the data collection process 80 questionnaires were completed, representing a population of $N=80$ households that participated. This translates to a response rate of $86 \%$ for the study. 


\subsection{Demographics}

Table 1 summarises the demographic information of the respondents in the survey. The data shows that $32 \%$ of respondents were male, while $68 \%$ were female. This is a typical characteristic of predominantly rural areas where the males are the sole breadwinners and work in the Park or are employed in the urban areas. The majority (34\%) of the respondents were in the 25-34 age groups, followed by $28 \%$ in the $20-24$ age group, $23 \%$ in the $35-44$ age group and $15 \%$ being 45 and above. At least $67 \%$ of the respondents had a Matric education (high school), with $3 \%$ having a post high school qualification, and $30 \%$ not having completed high school.

Table 1: Demographic Information

\begin{tabular}{|c|c|c|c|c|c|c|c|c|}
\hline \multicolumn{2}{|c|}{ Gender } & \multicolumn{4}{|c|}{ Age } & \multicolumn{3}{|c|}{ Educational Level } \\
\hline Male & Female & $20-24$ & $25-34$ & $35-44$ & $45+$ & Little/No Formal Education & Matric(High School) Certificate & Post High School \\
\hline $32 \%$ & $68 \%$ & $28 \%$ & $34 \%$ & $23 \%$ & $15 \%$ & $30 \%$ & $67 \%$ & $3 \%$ \\
\hline
\end{tabular}

\section{Source: Field Data}

\subsection{Summary of Results}

Table 2 summarises the findings of the study on a Likert Scale. Respondents were asked a series of pre-determined questions in the form of statements and were asked to respond to what extent they agreed with the statement, ranging on a 5-point scale from 1 (Strongly Agree) to 5 (Strongly Disagree), with 3 being Neutral.

Table 2: Summary of Results

\begin{tabular}{|c|c|c|c|c|c|c|c|c|c|c|c|c|}
\hline & \multicolumn{2}{|r|}{ SA } & \multicolumn{2}{|r|}{ A } & \multicolumn{2}{|r|}{$\mathbf{N}$} & \multicolumn{2}{|r|}{ D } & \multicolumn{2}{|r|}{ SD } & \multicolumn{2}{|c|}{ Total } \\
\hline & $f$ & $\begin{array}{l}\% \text { Freq } \\
\mathrm{N}=80\end{array}$ & $f$ & $\begin{array}{l}\% \text { Freq } \\
\mathrm{N}=80\end{array}$ & $f$ & $\begin{array}{c}\% \text { Freq } \\
\mathrm{N}=80\end{array}$ & $f$ & $\begin{array}{l}\text { \%Freq } \\
\mathrm{N}=80\end{array}$ & $f$ & $\begin{array}{l}\% \text { Freq } \\
\mathrm{N}=80\end{array}$ & $f$ & $\begin{array}{c}\% \text { Freq } \\
\mathrm{N}=80\end{array}$ \\
\hline My interaction with tourists has been positive & 12 & 15.0 & 16 & 20.0 & 18 & 22.5 & 12 & 15.0 & 22 & 27.5 & 80 & 100 \\
\hline Tourism has a negative impact on my community & 22 & 27.5 & 7 & 8.8 & 27 & 33.8 & 11 & 13.8 & 13 & 16.3 & 80 & 100 \\
\hline $\begin{array}{l}\text { Tourism has a positive impact on the quality of life in } \\
\text { my community }\end{array}$ & 37 & 46.3 & 8 & 10.0 & 15 & 18.8 & 12 & 15.0 & 8 & 10.0 & 80 & 100 \\
\hline My community has generally benefitted from tourism & 38 & 47.5 & 8 & 10.0 & 20 & 25.0 & 9 & 11.3 & 5 & 6.3 & 80 & 100 \\
\hline $\begin{array}{l}\text { Tourism has created employment opportunities in my } \\
\text { community }\end{array}$ & 31 & 38.8 & 14 & 17.5 & 27 & 33.8 & 4 & 5.0 & 4 & 5.5 & 80 & 100 \\
\hline My standard of living has improved due to tourism & 33 & 41.3 & 19 & 23.8 & 7 & 8.8 & 12 & 15.0 & 9 & 11.3 & 80 & 100 \\
\hline $\begin{array}{l}\text { Tourism has improved the infrastructure in my } \\
\text { community }\end{array}$ & 34 & 42.5 & 22 & 27.5 & 20 & 25.0 & 4 & 5.0 & 0 & 0 & 80 & 100 \\
\hline Tourism has introduced prostitution in my community & 27 & 33.8 & 6 & 7.5 & 12 & 15.0 & 30 & 37.5 & 5 & 6.3 & 80 & 100 \\
\hline $\begin{array}{l}\text { Tourism has contributed to an increase of social } \\
\text { problems in my community }\end{array}$ & 32 & 40.0 & 3 & 3.8 & 17 & 21.3 & 11 & 13.8 & 17 & 21.3 & 80 & 100 \\
\hline $\begin{array}{l}\text { The local authorities in my area can do more for my } \\
\text { community from the proceeds of tourism in the area }\end{array}$ & 43 & 53.8 & 31 & 38.8 & 5 & 6.3 & 1 & 1.3 & 0 & 0 & 80 & 100 \\
\hline
\end{tabular}

Key: $\mathrm{SA}=$ Strongly Agree, $\mathrm{A}=$ Agree. $\mathrm{N}=$ =Neutral, $\mathrm{D}=$ Disagree, $\mathrm{SD}=$ Strongly Disagree; $f=$ Frequency

\subsubsection{Interaction with Tourists}

As the results indicate, the majority of respondents (27.5\%) had negative interactions with tourists strongly disagreeing with the statement, while $15 \%$ disagreed with the statement. $20 \%$ of the respondents agreed with statement of having had a positive interaction with tourists and 15\% strongly agreed with statement. $22.5 \%$ were neutral. This finding represents a general (42.5\%) negative experience in interactions between the community and tourists.

\subsubsection{Negative Impact of Tourism on Community}

The majority of respondents (33.8\%) were neutral with regards to tourism having a negative impact on their community. Interestingly $27.5 \%$ and $8.8 \%$ of the respondents strongly agreed and agreed with the statement respectively, believing that tourism had a negative impact on their community. The remainder, $16.3 \%$ and $13.8 \%$ strongly disagreed and disagreed respectively with the statement. The result is significant as it indicates a general belief that there is no 
discernable impact of tourism in the area according to most respondents, however, a significant combined population (36.3\%) does believe that tourism has a negative impact on their community.

\subsubsection{Impact of Tourism on Quality of Life}

Significantly, $46.3 \%$ of the respondents admitted that tourism has had a positive impact on the quality of life in the community, while $10 \%$ agreed with the statement. $18.8 \%$ were neutral with regards to the impact of tourism on the quality of life in the area, while, 15\% and 10\% disagreed and strongly disagreed respectively with the statement. This finding indicates that there is a perceived improvement with regards to how people live in this community and this can be attributed to tourism.

\subsubsection{Community Benefits from Tourism}

Not surprisingly, the bulk of respondents (47.5\%) were of the strong opinion that their community had benefitted from tourism activities in the area, while $10 \%$ agreed. $25 \%$ were neutral on the community benefitting from tourism, while $11.3 \%$ and $6.3 \%$ disagreed and strongly disagreed respectively. Again this result indicates a general appreciation that tourism has resulted in benefits accruing to the community.

\subsubsection{Employment Creation attributed to Tourism}

The widely held view $(\mathrm{SA}=38.8 \%$ \& $\mathrm{A}=17.5 \%)$ is that tourism has created employment in the community in question. However, $33.8 \%$ of community members were neutral on this statement. While, a total minority of $10 \%$ of the respondents did not believe that tourism had created jobs in the community. This result fits into the previous aspects of community benefits and change in quality of life in the area since jobs related to tourism activities in the area have a causal effect on quality of life for rural families.

\subsubsection{Standard of living improvement due to Tourism}

This statement asked for individual opinions on the improvement of the standard of living for the respondent and his/her family. $41.3 \%$ of the respondents reported an improvement of their standard of living, strongly agreeing with the statement. Similarly, $23.8 \%$ of respondents agreed with the statement, while $8.8 \%$ were neutral and $15 \%$ and $11.3 \%$, disagreed and strongly disagreed with the statement respectively. This indicates a continuation in the theme that tourism activities had a positive impact on the community with regards to standard of living improvements, improvement in the quality of life in the area and accrual of benefits for locals.

\subsubsection{Infrastructural Improvement in the area}

The majority of respondents (42.5\%) indicated that they strongly agreed that infrastructure in their area had improved as a result of tourist activities in the area. With $27.5 \%$ agreeing with the statement, $25 \%$ were neutral, $5 \%$ disagreed and none of the respondents strongly disagreed with the statement. The result indicates that the community perceives tourism to have improved the infrastructure in the area to the benefit of the community.

\subsubsection{Introduction of Prostitution to the community as a result of tourism}

Prostitution has widely been viewed to be a social ill that follows the tourist industry and in this case the statement sought to determine the perceptions of respondents with regards to prostitution as a result of tourism activities in the area. This study found that the mostly widely held view was that tourism had not introduced prostitution to the area. $37.5 \%$ of respondents disagreed with the statement, while $6.3 \%$ strongly disagreed with the statement. However, a significant proportion of respondents (33.8\% and $7.5 \%$ respectively) believed that prostitution had been introduced in their community by tourism. $15 \%$ were neutral. This finding is consistent with the debate within communities with regards to some of the social ills that communities believe tourism brings to their communities. 


\subsubsection{Contribution of Tourism towards increased social problems}

$40 \%$ of the respondents strongly believed that tourism had contributed to an increase in the social problems in the sampled community. 3.8\% agreed, while, $21.3 \%$ were neutral. $13.8 \%$ and $21.3 \%$ disagreed and strongly disagreed respectively with the statement. This result illustrates that although tourism has perceived economic benefits for communities, one of the costs is social strife in the community, probably as a result of the utilisation of income within families and issues such as increases in food prices and access to amenities.

\subsubsection{Utilisation of Tourism proceeds for community improvement}

The results also indicate the sampled community believed that the local authorities could do much more with regards reinvesting the proceeds of tourism activities in the area back into their community. $53.8 \%$ of respondents strongly agreed with the statement while $38.8 \%$ agreed. $5 \%$ were neutral, while $1.3 \%$ disagreed and none of the respondents strongly disagreed with the statement. This finding is a re-occurring theme in rural tourism where communities believe that beneficiaries of tourism proceeds (local authorities) can be more sincere in their beneficiation of local rural communities from the proceeds of tourism in their locales.

\section{Discussion and Conclusion}

The findings of this study are significant in that the study focused on the perceptions of rural community members with regards to the perceived economic benefits of tourism to their community. The results indicate that the community members in the sampled population believed that tourism had made tangible improvements to the infrastructure in their community, had created jobs, and improved their living standards and the general quality of life in the area. However, issues such as prostitution and other social problems were also associated with tourism activities in the area and represented the cost aspect of tourism in rural areas. Although, most community members admitted to not having positive experiences with tourists to their area, it is important to note that the economic benefits of tourism to this community override the cost of tourism to the area.

Therefore, this paper concludes that although majority of the rural community may not have positive experiences with tourists and tourism, tourism does have significant economic benefits for the rural populace in the Skukuza area that borders the Kruger National Park of Limpopo Province, South Africa. It is important to note that as a result of this study it also emerged that the community believed that local authorities could do more with regards to re-investing the proceeds of tourism in the community. However, we recommend further qualitative study within the rural communities adjacent to the national park to further explore the socio-economic impact of tourism activities on the rural community. Such a study would further enrich the body of empirical research in the field of tourism studies, more-so the specific research focus on pro-poor tourism, while informing the local authorities on the potential areas for development and further community investment.

\section{References}

Ashley, C. \& Roe, D. (2002) Making tourism work for the poor: Strategies and challenges in Southern Africa. Development Southern Africa Journal, 19(1). Carfax Publishing.

Bahrami, R. \& Noori, K. (2013). Analysis of the role of tourism and its impact on rural develpment: Case study of the central part of Marivan. Technical Journal of Engineering and Applied Sciences, 3912), pp1074-1080.

Chachani, A. (2008). Tourism in India: Role in conflict and peace. Paper commissioned for the 2008 Travellers Philanthropy Conference, Arusha Tanzania.

Framgialli, F. (2008). Nigerian tourism development master plan. Institutional capacity strengthening to the tourism sector in Nigeria. Paper commissioned for the 2008 Travellers Philanthropy Conference, Arusha Tanzania.

Frechtling, D.C. (1994). Assessing the impacts of travel and tourism - measuring economic benefits. In Ritchie, J.R.B. \& Goeldner (Eds) Travel, tourism \& Hospitality research: A handbook for managers and researchers, $2^{\text {nd }}$ Ed, pp359-365. New York: John Wiley \& Sons.

Frechtling, D.C. (2011). Exploring the full economic impact of tourism for policy making: Extending the use of the tourism satellite account through macro-economic analysis tools. Presentation at the $3^{\text {rd }}$ UNWTO meeting of T20 Tourism Ministers, Paris France. October 25, 2011.

Holland, Jenny, Barian, M. \& Dixey, L. (2003). Tourism in poor rural areas. Diversifying the product and expanding the benefits in rural Uganda and Czech Republic. Pro-Poor Tourism Working paper No. 12. Economic and Social Research Unit (ESCOR) of the Department of the United Kingdom for International Development (DFID). 
Honey, M. \& Gilpin, R. (2009). Tourism in the developing world. Promoting peace and reducing poverty. Special Report 233. United States Institute of Peace. [Online] Available: https://www.usip.org. (Accessed May 23, 2014).

https://www.msu.edu/course/prr/840/econimpact/pdf/ecimpvol1.pdf. (Accessed May 23, 2014)

Lo, M.C, Songan, P, Mohamad, A.A. \& Yeo, A.W. (2013). Rural tourism and destination image: Community perception in tourism planning. The Macro-theme review, 2(1), pp102-118.

Mutana, Sarudazai (2013). Rural tourism for pro-poor development in Zimbabwean rural communities: Prospects in Binga rural district along lake Kariba. International Journal of Advanced Research in Management and Social Sciences, 2(4), 147-164.

Nzama A.T. (2008). Socio-cultural impacts of tourism on the rural areas within the world heritage sites. The case of KwaZulu Natal, South Africa. South Asian Journal of Tourism and Heritage, 1(1), pp1-8.

Rathore, N. (2012). Rural tourism impact, challenges and opportunities. ZENITH. International Journal of Business Economics and Management Research, 2(2), 252-260.

Stynes, J.D. (1997). Economic impacts of tourism. Michigan State University. [Online] Available:

Surugiu, Camelia. (2009). The economic impact of Tourism: An input-output analysis. National Institute for Research and Development in Tourism. Romania.

Thompson, E. (2007). Measuring the impact of tourism on rural development: An economic approach. MCRSA Presidential Symposium. JRAP, 37(2). [Online] Available: http://ageconsearch.umn.edu/bitstream/132415/2/07-2-7.pdf (Accessed May 23, 2014).

Tsundoda, T. \& Mendlinger, S. (2009). Economic and social impact of tourism on a small town: Peterborough, New Hampshire. Journal of Service Science and Management, (2), pp61-70.

Vellas, F. (2011). The indirect impact of tourism: An economic analysis. Presentation at the $3^{\text {rd }}$ UNWTO meeting of T20 Tourism Ministers, Paris France. October 25, 2011.

Viljoen, J. \& Tlabela, K. (2007) Rural tourism development in South Africa. Trends and Challenges. Human Sciences Research Council. HSRC Press.

Western, D. (2008). Ecotourism, conservation and development in East Africa: How the philanthropic traveller can make a difference. Paper commissioned for the 2008 Travellers Philanthropy Conference, Arusha Tanzania. 